\title{
The Effect of Project Manager's Leadership Style on Performance of Water Projects in Kenya
}

\author{
Dr. James T. Kariuki, PhD \\ Department of Management Science, University of Nairobi, Nairobi, Kenya
}

Doi:10.19044/esj.2018.v14n17p33～URL:http://dx.doi.org/10.19044/esj.2018.v14n17p33

\begin{abstract}
The objective of this study was to determine the relationship between project manager's leadership style and performance of water projects in Kenya. Operationalization of leadership style was based on transformation and transaction leadership style while project performance was based on project time and cost performance. The study analyzed secondary and primary data for 102 water projects that were completed between 2011 and 2014. Hierarchical regression analysis was undertaken on the variables. The results show that a significant relationship exist between project manager's leadership style and project time performance. In addition, the findings show that adoption of transformational leadership style leads to higher level of project performance. However, no significant relationship was established between project manager's leadership style and project cost performance. This may be due to the use of fixed price contracts that specify the conditions for escalation and the maximum allowable cost escalations which could have made cost changes insignificant. The study has provided empirical evidence on the relationship between project manager's leadership style and project performance within a developing country context. To enhance project time performance, project manager's leadership style is critical and managers should strive to intellectually stimulate project team members.
\end{abstract}

Keywords: Cost performance, Leadership Style, Project Performance, Time performance

\section{Introduction}

One of the most notable trends in both developed and developing countries is the increased number of projects. Projects are used by individuals, organizations and governments as means to achieve strategic goals. The British Standard (BS 6079:2000) defines a project as a unique set of coordinated activities, with definite starting and finishing point, undertaken by an individual or organization to meet specific performance 
objectives within defined schedule, cost and performance parameters. Due to increased emphasis on projects and the fact that the utility of a project depends upon successful project completion, project management field of study has emerged as a distinct discipline from general management (Cleland \& Ireland, 2002). Chase, et al. (2001) define project management as the process of planning, directing, and controlling resources in order to ensure high level of project performance which is normally expressed in terms of time, cost, quality and stakeholder satisfaction perspectives.

Despite the importance and emphasis on projects, the end results for most projects have not been exciting with majority of projects across different countries, industries and sectors registering poor performance. A review of extant literature on project performance shows that time and cost over-runs have become the norm rather than an exception (Jugdev \& Muller, 2005; Sambasivan \& Soon, 2007). Time and cost overruns normally results in litigations, wastage of resources, poor reputation of clients and professionals involved as well as lack of envisioned product, service or change (Aibinu \& Jagboro, 2002; Jugdev \& Muller, 2005). Thus, a key issue in academia and industries is what needs to be done to improve project performance.

Extant literature in general management shows a positive relationship between leadership style and organization performance (Dulewicz \& Higgs, 2005). Thus, a key concern in project management is whether project manager's leadership style can help to resolve the issue of poor project performance (Love, et al., 2011). Consequently, one stream of research that has gained prominence is on the impact of project manager's leadership style on project performance (Turner \& Muller, 2005; Yang, et al., 2011, Jiang, 2014). However, unlike in formal organizations setting, leadership in projects is complicated by involvement of different experts from organizations with diverse philosophies and practices, limited and predefined duration, individual project characteristics, conflict of interest and existence of temporary management structures that are formed to facilitate project execution (Clarke, 2012; Tyssen, et al., 2013).

Kenya is a water scarce country with renewable fresh water per capital being 647 cubic metres $\left(\mathrm{m}^{3}\right)$ against the United Nations recommended minimum of $1,000 \mathrm{~m}^{3}$ (Vision, 2030). To attain the recommended minimum and also economic, social and political aspirations as documented in the government blue print (Vision 2030), the Government of Kenya has prioritised provision of quality, affordable and sustainable water and sanitation services. Towards this end, several water projects have been implemented across the country. Financing of these projects has mainly been through government grants as well as grants and loans from development partners. Government spending in the water sector has been 
rising with total development expenditure increasing from Ksh 20.5 billion in 2012/13 to Ksh 43.9 billion in 2016/17 financial year (KNBS, 2018). For each project, there is a project manager who interacts with various parties/experts and is responsible for overall project performance.

\section{Problem Statement}

The need to enhance project performance has been on for several years and has resulted in identification of critical success factors (Chan \& Kumaraswamy, 1997; Assaf \& Al-Hejji, 2006). In spite of this, poor project performance seems to be a universal phenomenon in construction projects (Assaf \& Al-Hejji, 2006; Frimpong, et al., 2003). As noted earlier, leadership is a critical success factor in general management (Dulewicz \& Higgs, 2005) hence it would be expected that project manager's leadership style should influence project performance. However, an analysis of existing literature on project performance and the role of leadership has resulted in findings that are inconsistent. For instance, although several studies (Tabassi \& Babar, 2010; Kissi, et al., 2013) found transformational leadership to be a predicator of project performance, Keegan and Den Hartog (2004) found no significant link between transformation leadership style and project performance. Locally, majority of the studies on project performance have focused on determination of causes of time and cost overrun. For instance, Wainaina and Kagiri (2013) investigated causes of time and cost overruns in KenGen's power projects. On the other hand, Wainaina and Mwawasi (2016) studied causes of time and cost overruns in road construction projects.

Despite the importance of water projects to Kenya's social-economic development, the amount of resources invested and the fact that the utility of these projects depends upon successful completion, the performance of most projects in the water sector has been poor with majority experiencing time and cost over-run (Manyindo, 2009; Elliott \& Kimotho, 2013). Inconsistencies in international research findings on the relationship between project manager's leadership style, lack of local studies and poor project performance in Kenya triggered the need for this study. The objective of this study was to determine the relationship between project manager's leadership style and performance of water project in Kenya. The null hypothesis was that there is no significant relationship between project manager's leadership style and project performance.

\section{Literature Review}

Cole (1996) defines leadership as a dynamic process in which one individual influences others to contribute to the achievement of the group tasks. Although there is no universal definition, one key aspect is that leadership is a process hence time is needed for a leader to influence 
subordinates in the desired way. It is recognized that leaders influence followers differently by exhibiting a combination of traits, skills and behaviour which have resulted in different schools of thought or different leadership styles (Dulewicz \& Higgs, 2005; Turner \& Muller, 2005).

Hersey and Blanchard (1982) define leadership style as a consistent pattern of behaviour that a leader uses when working with and through people. Over the past decades, there have been six schools of leadership theories namely the trait, behavioural, contingency, visionary, emotional and competency school. Within visionary school, there is transformational and transactional leadership styles which were first articulated by Burns (1978) and later developed further by Bass $(1985,1990)$. Transformational leaders inspire followers to achieve objectives by raising their level of awareness, motivating them as well as addressing and modifying their values and selfesteem. In transformational leadership style there are four I's namely Idealized Influence, Inspirational Motivation, Intellectual Stimulation and Individualized Consideration (Bass \& Avolio, 1994).

Idealized Influence refers to the ability of the leader to exert influence by acting as a role model to followers while Inspirational Motivation refers to the ability of the leader to develop and articulate a compelling future vision as well as creating an image of success. Intellectual Stimulation arouses intelligence, rationality and focused problem solving by questioning assumptions, seeking differing perspectives and encouraging innovation and creativity. Individualised Consideration emphasises on the need for leaders to treat followers as individuals and not just as members of a group.

Transactional leadership style emphasises on contingency reward and management by exception. Contingency reward stresses on the leader agreeing with followers on the goals, responsibilities, operating structure and reward to be received upon achievement of set performance targets (Bass \& Avolio, 1994). Management by exception is categorised into two namely Management by Exception-Active and Management by Exception-Passive. Management by Exception-Active arises in cases where the leader actively monitors progress and initiates corrective action before things go wrong. In case of Management by Exception-Passive, the leader waits passively and only takes action when there are problems (Bass, 1985). As noted by Felfe, et al. (2004), transformational and transactional leadership styles exist in a continuum and are not independent of each other since a leader can combine certain aspects based on the circumstances. However, in most cases, one may identify the dominant style for a given leader.

According to Love, et. al. (2011), one of the key issues in project management is on what needs to be done to improve project performance. However, there is no consensus on project performance criteria that can be 
used across various projects (Khan, et al., 2014). This is partly due to the fact that different stakeholders view project performance differently and a project that is successful to the client may be considered unsuccessful by contractors or end users (Toor \& Ogunlana, 2010; Jugdev \& Muller, 2005).

One of the most commonly used project performance model is the completion of projects within time, cost and quality i.e. "the Iron Triangle" (Atkinson, 1999). Various researchers (Wateridge, 1995; Yu, et al., 2005) have criticised the use of iron triangle criteria due to its simplicity and have proposed inclusion of other aspects such as key stakeholders' satisfaction, future potential to the organisation, safety and customer's benefits. In spite of the criticism, the conventional measures of time and cost dominate performance measurement in the construction industry due to their objectivity (Pinto \& Slevin, 1988).

Based on time and cost performance evaluation criteria, projects may experience delays and cost over-runs. Assaf and Al-Hejji (2006) define project delay as the time over-run either beyond completion date specified in the contract or beyond the date that the parties agreed upon for the delivery of a project. On the other hand, Kaliba, et al. (2009) define cost overrun/escalation as the increase in the amount of money required to complete a project over and above the original budgeted amount. Thus, within this study, project performance was based on time performance and cost performance.

While leadership and leadership styles have been identified as critical factors in organisation performance, no consensus has been reached in the area of project performance (Kissi, et al., 2012; Muller \& Turner, 2012; Yang, et al., 2011). For instance, although Kissi, et al. (2013) found transformational leadership behavior of portfolio managers to be positively related to project performance, Keegan and Den Hartog (2004) found no significant relationship. In addition, although Prabhakar (2005) established that project manager's switches leadership styles during project execution, no significant correlation was found on its impact on project performance. Further, literature search by Turner and Muller (2005) found inadequate coverage of the relationship between project manager's leadership style and project performance.

\section{Research Methodology \\ Design, population and data collection}

A descriptive research design was used in the study. The population of the study comprised 102 water and sanitation projects completed in Kenya between 2011 and 2014. The study adopted a census approach due to the size of the population. Secondary and primary data was used in the study. Secondary data was collected from project files and reports. This data 
included budgeted project cost, actual project cost at the time of completion, budgeted project duration and actual project duration. Primary data was collected through administration of questionnaires to project managers and project team members (consultants, contractors and WSP representatives) that were involved in each of the identified projects. Two different questionnaires were used, one for the project managers and another for project team members and this helped to collect respondents' bio data and details of project manager's leadership style.

\section{Operationalization of variables and data analysis technique}

Based on the visionary theory, the independent variable was categorized into two variables namely transformational and transactional leadership styles. The two variables were further operationalized in line with the Multifactor Leadership Questionnaire with transformational leadership style having four sub-scales namely idealized influence, inspirational motivation, intellectual stimulation and individualized consideration while transactional leadership was operationalized into three sub-scales namely contingency reward, management by exception-active and management by exception-passive (Avolio, Bass \& Jung, 1999).

Based on studies by Muller and Turner (2007, 2010), Pinto and Slevin (1988) and Yang, et al., (2011), project time and cost were identified as measures of project performance. Further, based on Othman, et al. (2006); Dissanayaka and Kumaraswamy (1999), project time and cost were operationalized through Time Performance Index (TPI) and Cost Performance Index (CPI) respectively where;

$T P I=\frac{\text { Actual contract duration }}{\text { Projected contract duration }}$ and $\quad C P I=\frac{\text { Actual contract cost }}{\text { Budgeted contract cost }}$

The computed TPI specified the efficiency in which project activities were undertaken while CPI indicated the efficiency in which resources were utilized within the project. To determine the relationship between project manager's leadership style and project performance, data collected was analyzed using linear regression analysis. The regression equation was modelled as follows:

$P P=\beta_{o}+\beta_{1} I I+\beta_{2} I M+\beta_{3} I S+\beta_{4} I C+\beta_{5} C R+\beta_{6} M B E A+\beta_{7} M B E P+\epsilon$ where:

$P P=$ Project performance in terms of TPI or CPI

$I I=$ Idealised Influence

$I M=$ Inspirational Motivation

$I S=$ Intellectual Stimulation

$I C=$ Individualized Consideration

$C R=$ Contingency Reward 
$M B E A=$ Management by Exception - Active

$M B E P=$ Management by Exception - Passive

$\beta i$ 's $=$ regression coefficients

$\varepsilon=$ random error term

Data collected was subjected to tests of normality, multicollinearity and homoscedasticity. Shapiro-Wilk test which is more appropriate in testing normality for small sample sizes was used and data was found to be normally distributed. VIF statistics were computed for each of the variables and no multicollinearity was identified among the study variables. Homoscedasticity was tested through the use of Levene's test and the assumption of homoscedasticity was found to hold.

Since project performance was evaluated in terms of project time and cost performance, regression analysis was undertaken for each separately. The results were interpreted based on the adjusted R-squared, test of significance using $\mathrm{F}$ statistic, coefficients of the independent variables and their p-values.

\section{Results and Discussions}

a) Relationship between Project Manager's Leadership (PML) style and Time Performance Index (TPI).

Hierarchical multiple linear regression analysis was used to determine the contribution of each of the leadership style towards TPI. In step one, TPI was regressed on transformational leadership style while in step two, TPI was regressed on both transformational and transactional leadership styles and the results are presented in Table 1.

Results in model 1 indicate that $42.7 \%$ of the variance in TPI was explained by project manager's transformational leadership style while model 2 shows that $53.2 \%$ of the variance in project time performance was explained by both transformational and transactional leadership style.

The results in Table 1 also show that the two models were statistically significant with model 1 reporting a significant $F$ value of 13.473 $(\mathrm{p}=0.000)$ and model 2 with a significant $\mathrm{F}$ value of $11.875(\mathrm{p}=0.000)$. This implies that there is a statistically significant relationship between project manager's leadership style and project performance (based on TPI). In addition, based on change in $\mathrm{R}^{2}$, transactional leadership style accounts for $12 \%$ of the variance in project time performance. Thus, adoption of transformational leadership style would lead to higher level of project performance. 
Table 1: Regression Results of Time Performance Index and Project Manager's Leadership

\begin{tabular}{|c|c|c|c|c|c|}
\hline \multicolumn{6}{|c|}{$\begin{array}{c}\text { Style } \\
\end{array}$} \\
\hline & \multirow[t]{2}{*}{ Model } & \multirow{2}{*}{$\begin{array}{c}\text { Unstandardized } \\
\text { Coefficients } \\
\text { B }\end{array}$} & \multirow[b]{2}{*}{$\mathrm{t}$} & \multirow[b]{2}{*}{ Sig. } & $\begin{array}{c}\text { Collinearity } \\
\text { Statistic }\end{array}$ \\
\hline & & & & & VIF* \\
\hline \multirow{8}{*}{1} & (Constant) & 5.549 & 8.086 & .000 & \\
\hline & Idealized Influence & 0.144 & 0.435 & .665 & 2.983 \\
\hline & Inspirational Motivation & -0.515 & -2.242 & .028 & 3.268 \\
\hline & Intellectual Stimulation & -0.567 & -2.708 & .009 & 2.192 \\
\hline & Individual Consideration & -0.099 & -0.407 & .685 & 2.848 \\
\hline & R Square & 0.461 & & & \\
\hline & Adjusted $\mathrm{R}^{2}$ & 0.427 & & & \\
\hline & $\mathrm{F}$ & 13.473 & & .000 & \\
\hline \multirow{12}{*}{2} & $($ Constant $)$ & 2.083 & 1.755 & .084 & \\
\hline & Idealized Influence & -0.109 & -0.349 & .728 & 3.218 \\
\hline & Inspirational Motivation & -0.262 & -1.197 & .236 & 3.633 \\
\hline & Intellectual Stimulation & -0.485 & -2.529 & .014 & 2.259 \\
\hline & Individual Consideration & 0.103 & 0.458 & .649 & 2.989 \\
\hline & Contingent Reward & -0.187 & -0.891 & .377 & 1.899 \\
\hline & MBE Active & 0.756 & 3.083 & .003 & 2.428 \\
\hline & MBE Passive & 0.179 & 1.362 & .178 & 1.484 \\
\hline & R Square & 0.581 & & & \\
\hline & Adjusted $\mathrm{R}^{2}$ & 0.532 & & & \\
\hline & R Square change & 0.120 & & & \\
\hline & $\mathrm{F}$ & 11.875 & & .000 & \\
\hline
\end{tabular}

*With VIF being less than 10, there was no multicollinearity

For model 1, the significant predictors of project time performance were Inspirational Motivation $(\beta=-0.515, \mathrm{p}=0.028)$ and Intellectual Stimulation $(\beta=-0.567, p=0.009)$. For model 2 , the findings indicate that the significant predictor of project time performance were Intellectual Stimulation $(\beta=-0.485, p=0.014)$ and MBE Active $(\beta=0.756, p=0.003)$. Although the two models (model 1 and model 2 ) are statistically significant, model 2 is a better model as it accounts for a higher variation of the project time performance $(53.2 \%)$ compared to model $1(42.7 \%)$. Based on the above results, the predictive model for project time performance in Kenya is: $T P I=-0.485$ Intellectual Stimulation + o. 756 MBE Active

The predictive model implies that water project performance (in terms of TPI) in Kenya is a function of Intellectual Stimulation and MBE Active. Specifically, a unit increase in Intellectual Stimulation would result in a 0.485 reduction in TPI while a unit increase in MBE Active would result in a 0.756 increase in TPI. 


\section{b) Relationship between Project Manager's Leadership (PML) style and Cost Performance Index (CPI).}

Hierarchical multiple linear regression was used. First, CPI was regressed on transformational leadership style while in step two, CPI was regressed on both transformational and transactional leadership styles. However, the results of the two models were not statistically significant since model 1 had an $F$ value of $1.397(\mathrm{p}=0.245)$ while model 2 had $\mathrm{F}$ value of 0.806 ( $\mathrm{p}=0.586$ ). Given the results, there was not enough statistical evidence to suggest that a significant relationship exist between PML style and project performance (based on CPI).

\section{Discussion of Findings}

The finding of a statistically significant relationship between PML style and project performance (in terms of TPI) confirms the important role played by project managers in ensuring completion of project within stipulated time. The results of the study are consistent with the extant literature, for instance Kissi, et al. (2013) who found transformational leadership behavior of portfolio managers in United Kingdom to be positively related to project performance. In addition, the results confirm Keegan and Den Hartog (2004) assertion that transformational leadership style is critical in enhancing project performance.

The finding that both transformational and transactional leadership style accounts for a higher explanatory power are in line with findings by Felfe, et al. (2004) who had established that both transformational and transactional leadership styles aspects can be adopted by a leader based on the task at hand. These results support the visionary leadership theory and contingency theory which advocates for adoption of an appropriate leadership style based on the situation at hand.

On the relationship between PML style and project cost performance, no statistical significant relationship was found. One possible explanation could be due to the use of fixed price contract in water sector projects in Kenya. The fixed price contract limits cost adjustment by specifying conditions to be meet before project costs can be varied and also stating the maximum allowable cost variations. This means that even if a project has time over-run, it is not automatic that there would be cost adjustment. In addition, even in cases where cost adjustments are allowed due to various reasons, the maximum cost escalation limit may have resulted in insignificant changes in CPI.

\section{Conclusion of the Study}

The study concludes that there is a significant relationship between project manager's leadership style and project performance (in terms of time 
performance) with a unit increase in Intellectual Stimulation resulting in a 0.485 reduction in TPI while a unit increase in MBEA would result in a 0.756 increase in TPI. Thus, project managers in Kenya should engage project team members intellectually. For instance, project managers should interact more with team members to re-evaluate project assumptions, seek solutions to project challenges and design new ways of executing project activities.

\section{Recommendations for Further Research}

This study was based on water sector in Kenya. It is recommended that a similar study may be undertaken using project data from other sectors of the economy. In addition, since project performance was based on cost and time performance only, there is need for further research that would incorporate other aspects of project performance such as client satisfaction, stakeholder satisfaction and impact of the project on the environment.

\section{References:}

1. Aibinu, A. A., \& Jagboro, G. O. (2002). The effects of construction delays on project delivery in Nigerian construction industry. International Journal of Project Management, 20 (8), 593 -599.

2. Assaf, S., \& Al-Hejji, S. (2006). Causes of delays in large construction projects. International Journal of Project Management, 24(4), 349-357.

3. Atkinson, R. (1999). Project management: Cost, time and quality, two best guesses and a phenomenon, it's time to accept other success criteria. International Journal of Project Management, 17(6), 337342.

4. Bass, B. M. (1985). Leadership and performance beyond expectations. Free Press, Collier Macmillan.

5. Bass, B. M. (1990). From transactional to transformational leadership: Learning to share the vision. Organizational Dynamics, 18(3), 19-31.

6. Bass, B. M., \& Avolio, B. J. (1994). Transformational leadership and organizational culture. Public Administration Quarterly, 17 (1), 112117.

7. BS 6079-2 (BS 6079:2000): Project management and network planning part 2: British Standards Institute, London, U.K.

8. Burns, J. M., (1978), Leadership, N.Y, Harper and Row.

9. Chan, D. W., \& Kumaraswamy, M. M. (1997). A comparative study of causes of time overruns in Hong Kong construction projects. International Journal of Project Management, 15(1), 55-63. 
10. Chase R. B., Aquilano N. J., \& Jacobs F. R. (2001). Operations management for competitive advantage. $9^{\text {th }}$ Edition. McGraw-Hill Companies, Inc.

11. Clarke, N. (2012). Leadership in projects: What we know from the literature and new insights. Team Performance Management, 18 (3/4), $128-148$.

12. Cleland D. I., \& Ireland L. R. (2002). Project management: Strategic design and implementation. 4th Edition. The McGraw-Hill Companies, Inc.

13. Cole, G. A. (1996). Management: Theory and practice, 5th Ed. Ashford Color Press: London

14. Dissanayaka, S. M., \& Kumaraswamy, M. M. (1999). Evaluation of factors affecting time and cost performance in Hong Kong building projects. Engineering, Construction and Architectural Management, 6(3), 287-298.

15. Dulewicz, V., \& Higgs, M. (2005). Assessing leadership dimensions, styles and organizational context. Journal of Managerial Psychology, 20 (2), 105-123.

16. Elliot, R., \& Kimotho, J. (2013). Sangailu water project, Kenya. Retrieved April 5, from http://www.gov.gg/CHttpHandler.ashx ?id=82849\&p=0

17. Felfe, J., Tartler, K., \& Liepmann, D. (2004). Applied research in the field of transformational leadership. German Journal of Research in Human Resource Management, 18 (4), 262 - 288.

18. Frimpong, Y., Oluwoye, J., \& Crawford, L. (2003). Causes of delay and cost overruns in construction of groundwater projects in developing countries: Ghana as a case study. International Journal of Project Management, 21(5), 321-326.

19. Hersey, P., \& Blanchard, K. (1982). Management of organizational behavior. 4th Edition, Englewood Cliff, NJ: Prentice-Hall

20. Jiang, J. (2014). The study of the relationship between leadership style and project success. American Journal of Trade and Policy, 1(1), 51-55.

21. Jugdev, K., \& Muller, R. (2005). A retrospective look at our evolving understanding of project success. Project Management Journal, 36(4), 19-31.

22. Kaliba, C., Muya M., \& Mumba, K. (2009). Cost escalation and schedule delays in road construction projects in Zambia. International Journal of Project Management, 27(5), 522-531.

23. Keegan, A. E., \& Hartog, D. N. D. (2004), Transformational leadership in a project-based environment: A comparative study of 
the leadership styles of project managers and line mangers. International Journal of Project Management, 22 (8), 609-617.

24. Kenya National Bureau of Statistics. (2018). Economic Survey 2018. Nairobi, Government of Kenya.

25. Khan, M. S., Khan, I., \& Akhtar, B. Y. (2014). Styles of leadership and its impact upon the project success. Public Policy and Administration Research, 4 (11), 48-52.

26. Kissi, J., Dainty, A., \& Tuuli, M. (2012). Examining the role of transformational leadership of portfolio managers in projects performance. International Journal of Project Management, 31(4), 485-497.

27. Love, P. E. D., Edwards, D. J., \& Wood, E. (2011). Loosening the gordian knot: The role of emotional intelligence in construction. Engineering, Construction and Architectural Management, 1 (18), 50 $-65$.

28. Manyindo, J. (2009, October 9). Mzima water pipeline in Tsavo West National Park. Daily Nation, p. 9.

29. Muller, R., Geraldi, J., \& Turner, J. R. (2012). Relationships between leadership and success in different types of project complexities. Engineering Management, IEEE Transactions, 59 (1), 77 -90.

30. Othman, A. A., Torrance, J. V., \& Hamid, A. A. (2006). Factors influencing the construction time of civil engineering projects in Malaysia. Engineering, Construction and Architectural Management, 13(5), 481-501.

31. Pinto, J. K., \& Slevin, D. P. (1988). Project success: Definitions and measurement techniques. Project Management Journal, 19(1), 67 72.

32. Prabhakar, G. P. (2005). An empirical study reflecting the importance of transformational leadership on project success across twenty eight nations. Project Management Journal, 36 (4), 53-60.

33. Sambasivan, M., \& Soon, Y. W. (2007). Causes and effects of delays in Malaysian construction industry. International Journal of Project Management, 25(5), 517 -526.

34. Tabassi, A. A., \& Babar, S. (2010). Towards assessing the leadership style and quality of transformational leadership. The case of construction firms of Iran. Journal of Technology Management in China, 5 (3), 245-258.

35. Toor, S., \& Ogunlana, S. O. (2010). Beyond the 'iron triangle': Stakeholder perception of key performance indicators for large-scale public sector development projects. International Journal of Project Management, 28(3), 228-236. 
36. Wainaina, G., \& Kagiri, D. (2013). Time and cost overruns in power projects in Kenya: A case study of Kenya Electricity Generating Company Limited, ORSEA Journal, 6(1), 69-115.

37. Wainaina, G., \& Mwawasi, S. (2016). Time and cost overruns in road construction projects in Kenya under Kenya National Highways Authority. ORSEA Journal, 6(1), 117-156.

38. Tyssen, A. K., Wald, A., \& Spieth, P. (2013). Leadership in temporary organizations: A review of leadership theories and research agenda. Project Management Journal, 44 (6), 52 -67.

39. Yang, L. R., Huang, C. H., \& Wu, K. S. (2011). The association among project manager's leadership style, teamwork and project success. International Journal of Project Management, 29(3), 258267.

40. Yu, A. G., Flett, P. D., \& Bowers, J. A. (2005). Developing a value proposal for assessing project success. International Journal of Project Management, 23 (6), 428 - 436. 